\title{
Scenario-based earthquake hazard and risk assessment for Baku (Azerbaijan)
}

\author{
G. Babayev ${ }^{1}$, A. Ismail-Zadeh ${ }^{2,3,4}$, and J.-L. Le Mouël ${ }^{3}$ \\ ${ }^{1}$ Institute of Geology, National Academy of Sciences, Baku, Azerbaijan \\ ${ }^{2}$ Geophysikalisches Institut, Karlsruher Institut für Technologie, Karlsruhe, Germany \\ ${ }^{3}$ Institut de Physique du Globe de Paris, Paris, France \\ ${ }^{4}$ International Institute of Earthquake Prediction Theory and Mathematical Geophysics, \\ Russian Academy of Sciences, Moscow, Russia
}

Received: 1 September 2010 - Revised: 15 November 2010 - Accepted: 24 November 2010 - Published: 22 December 2010

\begin{abstract}
A rapid growth of population, intensive civil and industrial building, land and water instabilities (e.g. landslides, significant underground water level fluctuations), and the lack of public awareness regarding seismic hazard contribute to the increase of vulnerability of Baku (the capital city of the Republic of Azerbaijan) to earthquakes. In this study, we assess an earthquake risk in the city determined as a convolution of seismic hazard (in terms of the surface peak ground acceleration, PGA), vulnerability (due to building construction fragility, population features, the gross domestic product per capita, and landslide's occurrence), and exposure of infrastructure and critical facilities. The earthquake risk assessment provides useful information to identify the factors influencing the risk. A deterministic seismic hazard for Baku is analysed for four earthquake scenarios: near, far, local, and extreme events. The seismic hazard models demonstrate the level of ground shaking in the city: PGA high values are predicted in the southern coastal and northeastern parts of the city and in some parts of the downtown. The PGA attains its maximal values for the local and extreme earthquake scenarios. We show that the quality of buildings and the probability of their damage, the distribution of urban population, exposure, and the pattern of peak ground acceleration contribute to the seismic risk, meanwhile the vulnerability factors play a more prominent role for all earthquake scenarios. Our results can allow elaborating strategic countermeasure plans for the earthquake risk mitigation in the Baku city.
\end{abstract}

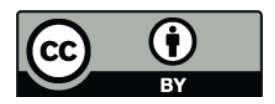

Correspondence to: A. Ismail-Zadeh (alik.ismail-Zadeh@kit.edu)

\section{Introduction}

Earthquake risk is a measure that combines, over a given time, the likelihood and the consequences of a set of earthquake scenarios (Beer and Ismail-Zadeh, 2003). The risk can be estimated as the probability of harmful consequences or expected losses (of lives and property) and damages (e.g. people injured, economic activity disrupted, environment damaged) due to an earthquake resulting from interactions between seismic hazards $(H)$, vulnerability $(V)$, and exposed values $(E)$. Conventionally, earthquake risk $(R)$ is expressed by the convolution of these three parameters: $R=H \otimes V \otimes E$. Each of those factors is disaggregated into the more specific parameters that comprise it. Seismic hazard is typically interrelated with the past seismicity, geological and geophysical parameters (e.g. peak ground acceleration, seismic intensity, seismic wave propagation and attenuation, site effect). Vulnerability depends on the quality of building structures, ground condition, and population features. Infrastructure, critical facilities, and important communication system represent the values exposed to damage due to an earthquake and should be taken into account in risk estimation. The proper approach to the problem of earthquake risk estimation and risk management should include consideration of all the contributing components.

The Baku city and the Absheron peninsula located on the north-western part of the South Caspian region (Fig. 1) experiences earthquakes from two primary sources: the subduction zone (Jackson et al., 2002) and shallow crustal faults. Uncertainties around the recurrence of earthquakes in this region combined with the Baku's growing exposure and the potentially high losses that could result from an extreme event has led to increasing concerns over seismic risk in the Baku city.

Published by Copernicus Publications on behalf of the European Geosciences Union. 


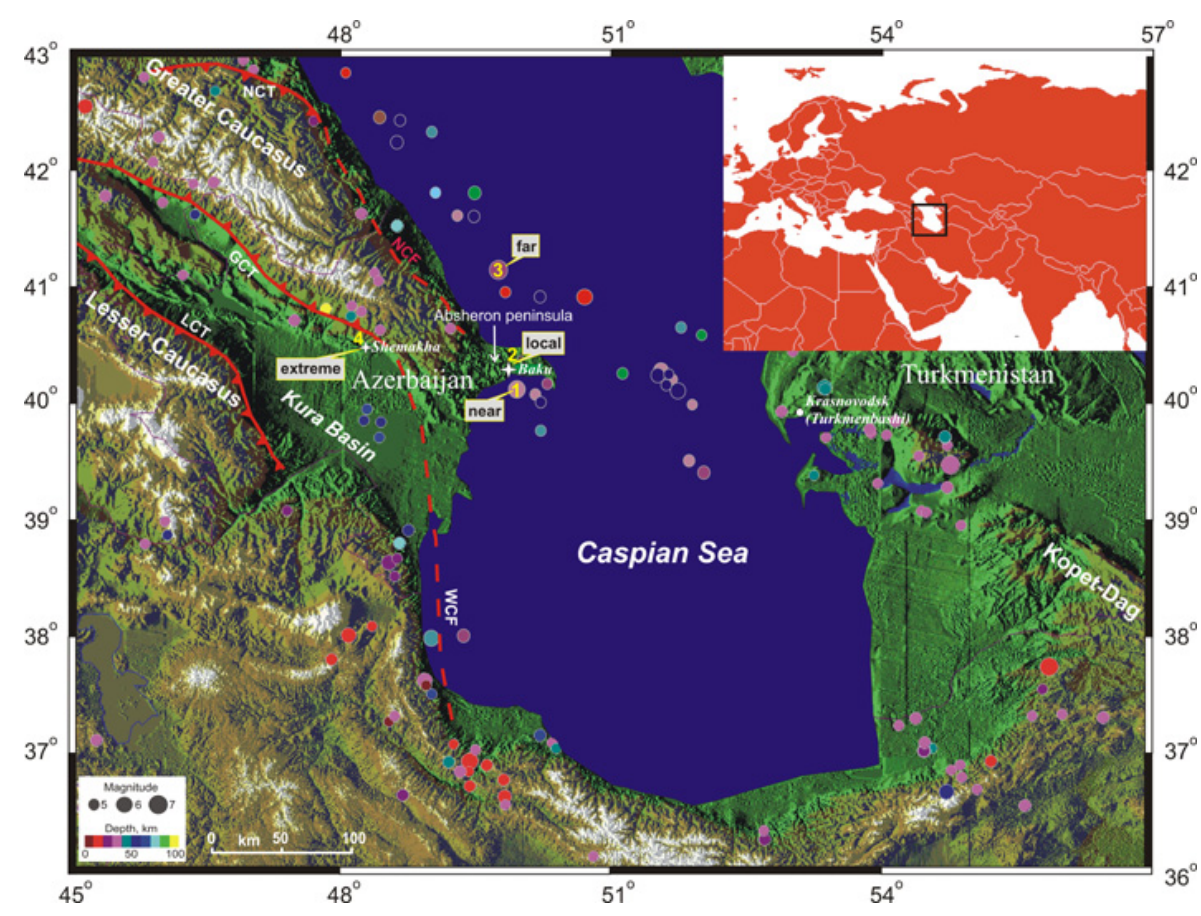

Fig. 1. Topography, simplified tectonics, and seismicity of the Caucasus to the Kopet-Dag region. The inset presents a map of central Eurasia showing the region's location. Earthquake epicentres are marked by circles, and the colours of the circles provide information on the depth of the earthquake hypocenters (earthquakes of magnitude 5 and greater for the period of 1950-2006 are plotted here). Target earthquakes are marked by numbers: (1), the $2000 M=6.3$ Caspian earthquake; (2), the $1935 M=3.5$ Surakhani earthquake; (3), the 1963 $M=6.5$ Caspian earthquake; and (4), the hypothetical extreme event in Shemakha. Abbreviations: NCT, North Caucasus thrust fault; GCT, Greater Caucasus thrust fault; LCT, Lesser Caucasus thrust fault; WCF, West Caspian fault; and NCF, North Caspian fault.

The Baku city, Absheron peninsula, and adjacent Caspian Sea are considered as areas of moderate seismic activity and of intensity VIII by the MSK-64 scale (Panahi, 2006), although the region is marked by a high seismic risk due to vulnerability of infrastructure and significant exposed values. The rapid industrial development of the city started in 1846, when the world's first oil well was drilled in BibiHeybat near Baku. In 1876 the Nobel brothers founded the first oil company and invited European engineers to work in Baku. At the beginning of the World War I Baku produced 7 million tons of oil a year, which constituted about $15 \%$ of world production at the time (Mir-Babayev, 2002). In 1920 the city became the capital of Azerbaijan Soviet Republic and underwent many major changes. During the Soviet era Baku extended significantly and now comprises the most of the southern part of the Absheron peninsula. With the break-up of the Soviet Union, the population of Baku densified tremendously due to a persistent migration of people from smaller towns and rural areas as well as from neighbouring countries. The intensified urbanization and an enormous increase in population density have substantially enhanced vulnerability of the city to earthquakes. Most recently the disaster risk has increased due to overcrowding, erroneous land-use planning, inadequately supervised building constructions, insufficient control of infrastructure devel- opment, and lack of environmental regulations. Due to these factors the consequences of an earthquake disaster in Baku are seen more severe.

In this paper we estimate an urban earthquake risk evaluating different factors and parameters contributing to the risk. The aim of the study is to assess seismic hazards for Baku based on various earthquake scenarios, to determine the vulnerability of the city to seismic events, to estimate exposed values, and finally to develop earthquake risk models for the considered earthquake scenarios. Our study is based on integrated analysis of seismicity, engineering geology, geomorphology, topography, soil conditions, ground and building conditions, population features, the gross domestic product per capita, and exposure of infrastructure and critical facilities.

\section{Geological setting and seismicity}

The Absheron peninsula is situated in the central part of the Alpine-Himalayan seismic belt and involved in dynamics of lithospheric structural units of the Arabian and Eurasian plates (Fig. 1). This lithosphere dynamics results in stress and strain localization and stress release in earthquakes, magmatic and mud volcanism, landslide processes, and other 
Table 1. Local earthquakes and strong events felt in Baku.

\begin{tabular}{|c|c|c|c|c|}
\hline $\begin{array}{l}\text { Data } \\
\mathrm{d} / \mathrm{m} / \mathrm{y}\end{array}$ & $\begin{array}{l}\text { Magnitude } \\
\text { Ms }\end{array}$ & $\begin{array}{l}\text { Depth } \\
\text { km }\end{array}$ & $\begin{array}{l}\text { Intensity } \\
\text { MSK-64 }\end{array}$ & $\begin{array}{l}\text { Earthquake location/ } \\
\text { Intensity in Baku }\end{array}$ \\
\hline 02/01/1842 & 5 & 3 & VIII & Mashtaga, near Baku/V \\
\hline $11 / 06 / 1859$ & $5.9 \pm 0.5$ & 10 & VIII-IX & Shamakha/V \\
\hline 28/01/1872 & $5.7 \pm 0.5$ & 7 & VIII-IX & Shamakha/IV \\
\hline 08/07/1895 & $8.2 \pm 0.3$ & 60 & $\mathrm{X}$ & Krasnovodsk/V-VI \\
\hline $13 / 02 / 1902$ & $6.9 \pm 0.2$ & 8 & VIII-IX & Shamakha/V \\
\hline 06/07/1910 & $4.4 \pm 0.5$ & 7 & VI-VII & Surakhani, near Baku/V \\
\hline 07/06/1911 & $6.4 \pm 0.3$ & 46 & VI-VII & Caspian Sea/VI \\
\hline 22/11/1922 & $4.3 \pm 0.7$ & 15 & V-VI & Absheron peninsula/VI \\
\hline 20/10/1931 & $6.2 \pm 0.5$ & 70 & VII-VIII & Caspian Sea \\
\hline 09/04/1935 & 6.3 & 100 & VI & Caspian Sea \\
\hline 24/06/1935 & 3.5 & 5 & $\mathbf{V}$ & Surakhani/Baku \\
\hline 06/09/1937 & 5 & 22 & $\mathrm{~V}-\mathrm{VI}$ & Absheron peninsula \\
\hline 23/02/1938 & 5.7 & 15 & VI & Baku \\
\hline 06/09/1938 & $5.0 \pm 0.5$ & 22 & VI & Caspian Sea (northern part) \\
\hline 05/03/1946 & $4.8 \pm 0.3$ & 11 & VII & Absheron peninsula \\
\hline 05/11/1958 & $4.0 \pm 0.5$ & 12 & $\mathrm{~V}-\mathrm{VI}$ & Caspain Sea \\
\hline 28/11/1958 & $2.2 \pm 0.7$ & 3 & $\mathrm{~V}$ & Baku \\
\hline 27/01/1963 & 6.5 & 30 & & Caspian Sea \\
\hline $15 / 10 / 1971$ & $4.0 \pm 0.5$ & 13 & VI & Caspian Sea \\
\hline 20/12/1971 & $5.5 \pm 0.1$ & 5 & VII & Absheron peninsula \\
\hline 20/12/1971 & $5.3 \pm 0.2$ & 12 & VII & Absheron peninsula \\
\hline 03/02/1972 & $4.9 \pm 0.2$ & 5 & VI & Absheron peninsula \\
\hline 26/10/1973 & 5.1 & 80 & & Absheron peninsula \\
\hline $14 / 12 / 1973$ & $5.1 \pm 0.2$ & 70 & $\mathrm{~V}$ & Caspian Sea (northern part) \\
\hline 02/08/1975 & 4.7 & 33 & & $51 \mathrm{~km}$ eastward from Baku \\
\hline 16/01/1979 & 4.4 & 10 & & Baku \\
\hline 23/02/1983 & 5.0 & 10 & V & Nardaran-Bilgah, near Baku \\
\hline 06/03/1986 & 6.3 & 33 & VIII & Caspian/V-VI \\
\hline 11/05/1986 & 4.5 & 15 & VI & Caspian/V \\
\hline 16/09/1989 & 6.5 & 55 & & Caspian/IV-V \\
\hline 06/01/1992 & 4.5 & 33 & & Baku \\
\hline $28 / 10 / 2000$ & 4.6 & 33 & & Caspian Sea \\
\hline 25/11/2000 & 5.8 & 40 & VII & Caspian Sea \\
\hline $25 / 11 / 2000$ & 6.3 & 33 & VIII & Caspian Sea \\
\hline 06/12/2000 & 7.3 & 33 & IX & West Turkmenistan/IV \\
\hline 07/01/2001 & 5.5 & 48 & IV-V & Caspian Sea/IV-V \\
\hline $11 / 02 / 2002$ & 5.3 & 38 & IV & Caspian Sea \\
\hline 04/10/2003 & 4.1 & 10 & & $20 \mathrm{~km}$ southwest from Baku \\
\hline $24 / 10 / 2003$ & 4.6 & 33 & & $34 \mathrm{~km}$ northeast from Baku \\
\hline
\end{tabular}

The bold-marked events are used as the earthquake scenarios to assess seismic hazard and to evaluate earthquake risk.

active geological and geophysical processes (Panahi, 2003). Global Positioning System (GPS) surveys across the Greater and Lesser Caucasus provide the shortening rate of $10 \pm$ $2 \mathrm{~mm} \mathrm{yr}^{-1}$ (Reilinger et al., 1997). The measured deformations confirm that the Absheron peninsula is positioned at the junction of active fault systems (Fig. 1): the Greater (GCT) and Lesser (LCT) Caucasus thrust faults, North Caucasian thrust fault (NCT), the north Caspian (NCF) and west Caspian (WCF) right-lateral strike slip faults. The ArabianEurasian collision continues to be accommodated by shorten- ing and lateral displacement of the lithosphere out of the collision zone along the right-lateral strike-slip faults (Kadirov et al., 2008; Reilinger et al., 2006). The regional tectonic processes and lithosphere deformations give rise to earthquakes that have devastated the Caucasus region throughout recorded history (e.g. the 1902 Shemakha earthquake; Veber, 1904).

The Absheron peninsula together with the part of the Absheron water area (the Azerbaijan sector of the Caspian Sea) is located in the south-eastern extremity of the Greater 
Caucasus, where the mountain range is dying out. Earthquakes in the region migrate along the Alpine-Himalayan seismic belt (Ismail-Zadeh 1996) and are associated with the fault zones located either in the peninsula itself, in the Azerbaijan sector of the Caspian Sea or in the adjacent folding structures of the Greater Caucasus and Kopet-Dag (Fig. 1).

Two earthquake-prone areas (the northern and southern zones) can be distinguished in the Absheron peninsula (Agamirzoyev, 1987). The northern zone is considered to be a continuation of the North Caucasus thrust fault system and the North Caspian fault (NCT and NCF in Fig. 1) through the northern coastal part of the Absheron peninsula and the Caspian Sea (Absheron sill) to the western Turkmenistan. The seismic activity in the northern zone is relatively high with earthquakes of magnitude greater than 6 . Allen at al. (2002) and Jackson et al. (2002) proposed that the earthquakes within this zone are associated with the ongoing NE-subduction of the South Caspian basement beneath the Absheron sill. The $1842 M=5$ Mashtaga destructive earthquake ( $25 \mathrm{~km}$ to the northeast from Baku), $1983 M=5$ Nardaran-Bilgah, and $1989 M=6.5$ Caspian earthquakes occurred within the northern zone. The southern zone is likely to be a continuation of the Greater Caucasus thrust fault (GCT, Fig. 1) through the offshore part of the Absheron Peninsula and the Caspian Sea to the south-western part of Turkmenistan. The strong $2000 M=6.3$ Caspian earthquake occurred in the southern zone $(35 \mathrm{~km}$ to the south from Baku): the main shock together with numerous aftershocks caused 35 casualties, 1289 damaged and 3 collapsed buildings.

The first information on the earthquakes in the region can be found in old Arabic chronicles, hand-writings, notes of pilgrims etc. Modern period in regional seismology started after the 1902 Shemakha earthquake. The Shemakha town (located about $110 \mathrm{~km}$ west of the Baku city) repeatedly suffered from strong earthquakes in the past. Recorded destructive earthquakes occurred in Shemakha in 1191, 1667 (with a death toll of about 80000 people), and 1859 (according to Veber, 1904). On 13 February 1902 a catastrophic event struck the region again. The intensity of the earthquake in the epicentral area was X (the maximal intensity on the Rossi-Forel scale, which is characterized as an earthquake of extreme intensity). The earthquake resulted in ruins in the town, rock falls, landslides, and activated mud volcanoes. The earthquake intensity in the Shemakha town was estimated as IX to X (Boghdanovitch, 1904). The earthquake generated a moderate ground shaking in Baku and minor damage (e.g. cracks in some buildings). Highamplitude waves were observed in the Caspian Sea adjacent to Baku casting boats and yachts ashore (Levitski, 1902). The tsunami-like waves were likely to be generated by an underwater landslide or rocks sliding offshore, both induced by the ground shaking due to the Shemakha earthquake. While the magnitude of the 1902 Shemakha earthquake was estimated to be $6.9 \pm 0.2$ (Kondorskaya et al., 1982), the earth- quake magnitude could be higher as 7.3 considering the duration of ground shaking of about 30-40 s and the length of the ruptured area of about $80 \mathrm{~km}$ (Levitski, 1902; Boghdanovitch, 1904).

The first seismic station was set up in Baku by the Nobel brothers in 1903 to study the seismicity of the Absheron peninsula and to provide the countermeasures against consequences of a potential destructive earthquake (Charbe, 1904). Until the end of the last century 14 seismic stations were operating in Azerbaijan. In the last decade, 20 digital telemetric seismic stations of ISMES Spa (6 stations) and Kinemetrics (14 stations) were installed in Azerbaijan with the center for data collection and processing in Baku.

For this study we compiled a catalogue of earthquakes based on two sub-catalogues. The first sub-catalogue consists of 229 earthquakes of magnitudes greater than 4.0 (covering the period from 1831 to 2003) and is compiled using the local published and electronic catalogues (Kondorskaya et al., 1982; Sultanova, 1986; National Earthquake Information Center 1977-2001; Gasanov 2003). The second subcatalogue is restricted to the period of instrumental observations (1931-2003) and consists of 217 earthquakes of magnitudes greater than 4.0. Table 1 lists the earthquakes in Baku, the Absheron peninsula, and in the adjacent region felt in Baku between 1842 and 2003.

\section{Seismic hazard assessment}

Seismic hazard assessment in terms of engineering parameters of strong ground motion (namely, peak ground acceleration - PGA, and seismic intensity) is based on the information about the features of earthquake ground motion excitation, seismic wave propagation (attenuation), and site effect in the region under consideration and combines the results of seismological, geomorphological, geological, and tectonic investigations (e.g. Ismail-Zadeh et al., 2007). Two principal methods are intensively used in seismic hazard assessment: probabilistic (PSHA) and deterministic (DSHA). PSHA determines the probability rate of exceeding various levels of ground motion estimated over a specified period of time (Cornell, 1968). Although the PSHA considers uncertainties in earthquake source, path, and site conditions, there are several points of criticism related to this assessment: e.g., validity of a point source model; ground motion uncertainties in the mathematical formulation of the method; and incapability to correctly model the dependencies between large numbers of uncertain random parameters (Klügel et al., 2006; Panza et al., 2010). DSHA is an alternative method for hazard analysis and is based on a specified earthquake scenario. For a given earthquake, the DSHA model analyses the attenuation of seismic energy with distance to determine the level of ground motion at a particular site. Ground motion calculations capture the effects of local site conditions and use the available knowledge on earthquake sources and 
wave propagation processes. Namely, attenuation relationships are used for a given earthquake magnitude to calculate ground shaking demand for rock sites, which is then amplified by factors based on local soil conditions. Although the occurrence frequency of the ground motion is usually not addressed in DSHA, the method is robust for an assessment of seismic hazard due to specified events and remains a useful approach for a decision-making.

We use a scenario-based deterministic approach in a view of the limited seismological data and the local irregularities associated with strong events. For the deterministic seismic hazard assessment, we select four target earthquake scenarios. The selection of these target earthquake scenarios was based on the following criteria: (i) the distance of the epicenter of the event from Baku, (ii) the magnitude of the event; (iii) the effect of the earthquake on the study area, (iv) the event location with respect to the regional fault system, and (v) the re-occurrence of the event within the certain time interval. We consider the $2000 M=6.3$ Caspian earthquake (the epicentre was located $35 \mathrm{~km}$ southward from Baku) as a near event (marked by 1 in Fig. 1); the 1935 $M=3.5$ Surakhani earthquake (epicentre was located in the Baku area) as a local event (marked by 2); the $1963 M=6.5$ Caspian earthquake (100 km northward from Baku) as a far event (marked by 3); and a hypothetic $M=7.5$ earthquake in Shemakha (110 km westward from Baku) as an extreme event (marked by 4). The need to employ historical extreme events in seismic hazard studies is highlighted by the recent disaster event (the 12 January $2010 M=7$ Haiti earthquake). The probabilistic seismic hazard model for the region did not take into account historical large earthquakes, and hence the surface peak ground acceleration was significantly underestimated (USGS, 2010).

Theoretical and empirical estimations of the physical parameters of the ground, the thickness and lithology of soil, the soil amplification, attenuation, and dynamic properties of the ground in the region were studied on the basis of drilled borehole data and seismic and geological profiles (Babayev, 2006; Midorikawa et al., 1992). The Baku city is divided into $28 \times 20$ quadratic cells $(100 \mathrm{~m} \times 100 \mathrm{~m}$ each $)$ in our models; the location of the study region is shown in Fig. 2. For each cell the bedrock and surface PGA are determined using seismic parameters for selected earthquake events. To estimate the expected bedrock PGA in the region, we use the following relationships between the peak ground acceleration $A$ (in gal $=10^{-2} \mathrm{~m} \mathrm{~s}^{-2}$ ), the magnitude $M$, and the hypocentral distance $R$ (in $\mathrm{km}$ ):

$\log A=0.28 M-0.8 \log R+1.7$

for $A>160 \mathrm{gal}$ (for near-field events), and

$\log A=0.28 M-2.3 \log R+0.8$

for $A<160 \mathrm{gal}$ (for far-field events). Derived empirically by Aptikayev and Kopnichev (1979), relationships (1) and (2)
Table 2. Subsurface models for the Baku city.

\begin{tabular}{|c|c|c|c|}
\hline Model & $\begin{array}{l}\text { Thickness } \\
\text { of sediments } \\
\text { (m) }\end{array}$ & Age & Lithology \\
\hline A1 & $\begin{array}{l}5 \\
1010\end{array}$ & $\begin{array}{l}\mathrm{Q} \\
\mathrm{N}\end{array}$ & $\begin{array}{l}\text { sand, clay, sandstone } \\
\text { tuff, breccia, shale }\end{array}$ \\
\hline A2 & 71200 & $\begin{array}{l}\mathrm{Q} \\
\mathrm{N}\end{array}$ & $\begin{array}{l}\text { sand, gravel, pebble with sand } \\
\text { intrusion argillaceous limestone }\end{array}$ \\
\hline A3 & $\begin{array}{l}4 \\
1200\end{array}$ & $\begin{array}{l}\mathrm{Q} \\
\mathrm{N}\end{array}$ & $\begin{array}{l}\text { clay, loam, sandy loam } \\
\text { argillaceous limestone }\end{array}$ \\
\hline A4 & 1200 & $\mathrm{~N}$ & $\begin{array}{l}\text { Pliocene clay, tuff, } \\
\text { argillaceous sandstone }\end{array}$ \\
\hline B1 & $\begin{array}{l}5 \\
5 \\
1200\end{array}$ & $\begin{array}{l}\mathrm{Q} \\
\mathrm{Q} \\
\mathrm{N}\end{array}$ & $\begin{array}{l}\text { sandy loam with gravel } \\
\text { sand, clay, soft-weathered limestone } \\
\text { clay, argillaceous limestone }\end{array}$ \\
\hline $\mathrm{C} 1$ & $\begin{array}{l}4 \\
5 \\
20 \\
3800\end{array}$ & $\begin{array}{l}\mathrm{Q} \\
\mathrm{Q} \\
\mathrm{Q} \\
\mathrm{N}\end{array}$ & $\begin{array}{l}\text { sand, gravel-pebble } \\
\text { clay, argillaceous sand } \\
\text { clay } \\
\text { clay, sand, argillaceous } \\
\text { sandstone and limestone }\end{array}$ \\
\hline $\mathrm{C} 2$ & $\begin{array}{l}7 \\
7 \\
23 \\
3200\end{array}$ & $\begin{array}{l}\mathrm{Q} \\
\mathrm{Q} \\
\mathrm{Q} \\
\mathrm{N}\end{array}$ & $\begin{array}{l}\text { sand, water-saturated sand } \\
\text { clay, pebble, soft-weathered } \\
\text { limestone, shale } \\
\text { clay, sand } \\
\text { clay, organic clay, } \\
\text { argillaceous sandstone }\end{array}$ \\
\hline $\mathrm{C} 3$ & $\begin{array}{l}7 \\
5 \\
20 \\
1500\end{array}$ & $\begin{array}{l}\mathrm{Q} \\
\mathrm{Q} \\
\mathrm{Q} \\
\mathrm{N}\end{array}$ & $\begin{array}{l}\text { Limestone } \\
\text { Limestone } \\
\text { clay, sand, limestone } \\
\text { argillaceous limestone } \\
\text { and sandstone }\end{array}$ \\
\hline $\mathrm{C} 4$ & $\begin{array}{l}5 \\
5 \\
20 \\
1910\end{array}$ & $\begin{array}{l}\mathrm{Q} \\
\mathrm{Q} \\
\mathrm{Q} \\
\mathrm{N}\end{array}$ & $\begin{array}{l}\text { sand with sandstone } \\
\text { sand, clay, sandstone } \\
\text { sand, clay, sandstone } \\
\text { sand, sandstone, organic clay }\end{array}$ \\
\hline D1 & $\begin{array}{l}5 \\
23 \\
1200\end{array}$ & $\begin{array}{l}\mathrm{Q} \\
\mathrm{Q} \\
\mathrm{N}\end{array}$ & $\begin{array}{l}\text { sand } \\
\text { sand with sandstone } \\
\text { sandstone, aleurite }\end{array}$ \\
\hline D2 & $\begin{array}{l}7 \\
20 \\
1200\end{array}$ & $\begin{array}{l}\mathrm{Q} \\
\mathrm{Q} \\
\mathrm{N}\end{array}$ & $\begin{array}{l}\text { sand, clay, limestone } \\
\text { clay, sand } \\
\text { shale, tuff, sandstone }\end{array}$ \\
\hline D3 & $\begin{array}{l}7 \\
20 \\
1500\end{array}$ & $\begin{array}{l}\mathrm{Q} \\
\mathrm{Q} \\
\mathrm{N}\end{array}$ & $\begin{array}{l}\text { sand with sandstone } \\
\text { clay, sand } \\
\text { aleurite, shale, conglomerate }\end{array}$ \\
\hline D4 & $\begin{array}{l}7 \\
20 \\
1390\end{array}$ & $\begin{array}{l}\mathrm{Q} \\
\mathrm{Q} \\
\mathrm{N}\end{array}$ & $\begin{array}{l}\text { limestone, sands } \\
\text { sand, clay, limestone } \\
\text { conglomerate, dolomite, tuff, } \\
\text { sandstone, breccia, shale }\end{array}$ \\
\hline
\end{tabular}

Models C1, C2, and D4 correspond to three typical subsurface models. Notations: Q, Quaternary; and N, Neogene.

are well suited for soft to hard bedrocks, typical for the Absheron peninsula bedrocks. We compare the relationships (1) and (2) with the empirical relationship between PGA, 


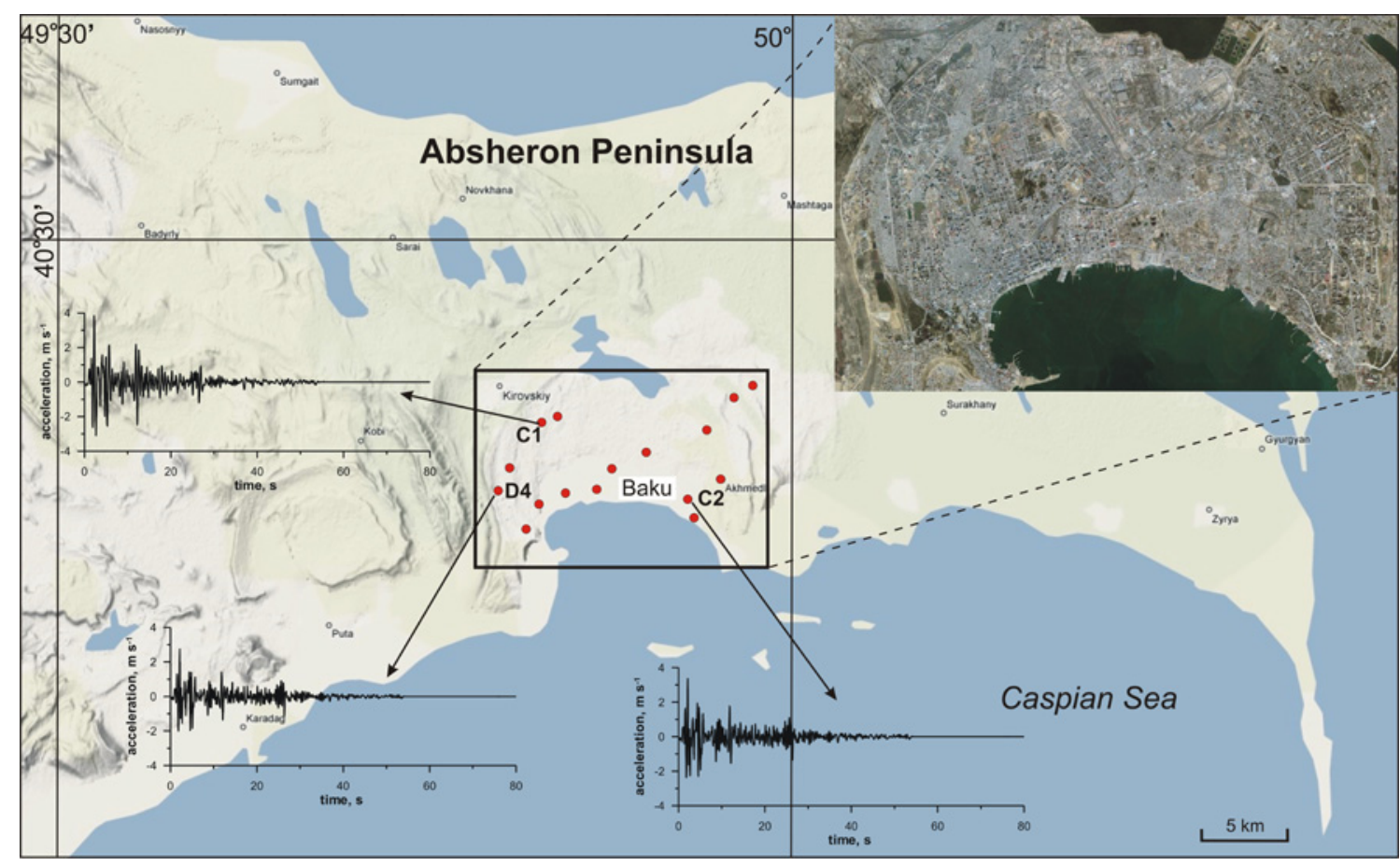

Fig. 2. Topography of the Absheron peninsula and the location of the studied region (solid rectangular). The dots indicate the sites of drilled boreholes; the geological and geophysical data from these boreholes were used in this study. The modelled accelerograms are presented for three typical subsurface models C1, C2, and D4 (see Table 2 for the subsurface model description). Satellite image of the study region (Baku city) is presented in the inset.

magnitude, hypocentral distance, and focal depth $H$ used for intra-plate earthquakes in Japan (e.g., Tonouchi and Kaneko, 1984):

$$
\begin{aligned}
\log A & =0.5 M+0.0043 H \\
& -\log \left(R+0.0055 \times 10^{0.5 M}\right) \\
& -0.003 R+0.83 .
\end{aligned}
$$

The comparison shows a good agreement between the attenuation relationships (Fig. 3) and hence provides a sound ground for the use of formulas Eqs. (1) and (2). Using the PGA values at bedrock as the seismic input motion parameters of the model, all dynamic parameters of both subsurface soil and the surface PGA can be determined.

Site effects, detailed surface geology, the amplification factor, and the seismic response of subsurface soil have been analysed to determine the surface motion acceleration for the study area. The subsurface structure down to the seismic bedrock is modelled by the horizontally multi-layered structure, in which shear-wave velocity, thickness, and density vary with layers. The $P$-wave velocities measured in several boreholes are used to develop the subsurface ground model for each cell and to identify types of sediments, their thickness, and variations of underlying rock layers. The subsurface models used in our study are presented in Table 2; one of these subsurface models is assigned to each model

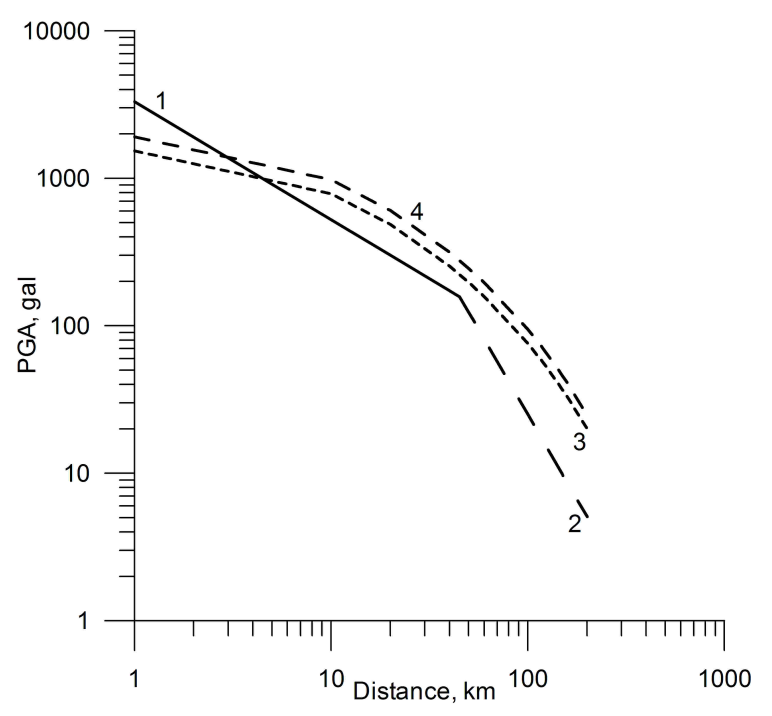

Fig. 3. PGA vs. the distance from an earthquake hypocenter computed for events of magnitude 6.5. Curves 1 and 2 mark the "near" and "far" events in Baku and are plotted using the formulas Eq. (1) and Eq. (2), respectively. Curves 3 and 4 mark the intra-plate events in Japan occurred at the depths of $33 \mathrm{~km}$ and $55 \mathrm{~km}$, respectively, and are plotted using the formula Eq. (3). See text for detail. 
Table 3. Physical parameters of the principal soil units in the Absheron peninsula.

\begin{tabular}{lllll}
\hline Lithology & $\begin{array}{l}\text { Measured } \\
P \text {-wave velocity } \\
V_{P}, \mathrm{~km} \mathrm{~s}^{-1}\end{array}$ & $\begin{array}{l}\text { Calculated } \\
S \text {-wave velocity } \\
V_{S}, \mathrm{~km} \mathrm{~s}^{-1}\end{array}$ & $\begin{array}{l}\text { Density } \\
\mathrm{g} \mathrm{cm}^{-3}\end{array}$ & $\begin{array}{l}\text { Amplification } \\
\text { factor }\end{array}$ \\
& 1.9 & 0.557 & 1.90 & 0.90 \\
\hline Quaternary clay & 1.1 & 0.289 & 1.80 & 1.19 \\
Sandy clay & 1.2 & 0.320 & 1.81 & 1.14 \\
Sand (Paleogene - Neogene) & 1.3 & 0.351 & 1.82 & 1.10 \\
Quaternary sandy clay & 4.0 & 1.681 & 2.32 & 0.57 \\
Limestone (Pliocene - Quaternary) & & & & \\
Shellstone, soft weathered limestone & 1.0 & 0.260 & 1.79 & 1.25 \\
(Paleogene - Neogene and Quaternary) & & 0.351 & 1.82 & 1.10 \\
Sandy clay (Paleogene-Neogene) & 1.3 & 0.848 & 2.01 & 0.76 \\
Sandstone (Miocene - Quaternary) & 2.6 & 0.189 & 1.76 & 1.43 \\
Eolian-delluvial (modern deposits) & 0.75 & 0.231 & 1.78 & 1.31 \\
Mild clay (Pliocene - Quaternary) & 0.9 & 0.217 & 1.77 & 1.35 \\
Loamy sands & 0.85 & 0.450 & 1.86 & 0.99 \\
Conglomerates (Miocene - Quaternary) & 1.6 & 0.269 & 1.79 & 1.23 \\
Pebble with sandy intrusions & 1.03 & 0.162 & 1.75 & 1.52 \\
Forestry mild clays & 0.65 & & \\
\hline
\end{tabular}

cell (see Table S1 in the Supplement for the distribution of the subsurface models in the cells).

A surface PGA is calculated by a multiplication of the bedrock PGA beneath the cell (as the input acceleration) with the amplification factor of the subsurface structure beneath the cell (Tonouchi and Kaneko, 1984). The amplification factor (and the relevant accelerogram) for all subsurface models (except model A4) has been determined using the SHAKE software (Schnabel et al., 1972). The SHAKE method assumes that the soil system extends infinitely in the horizontal direction and the responses in a soil deposit are caused by the upward propagation of shear waves from the underlying rock formation. Non-linear site effects, such as an increase in damping and reduction in shear wave velocity with an increase in input strength, are observed in the dynamic loading of soils (Idriss and Seed, 1968). SHAKE simulates a non-linear dynamics of the subsurface soil and sediments by using stress-dependent soil properties and requires, as input data, the values of the shear wave velocity, density, thickness, shear modulus, and damping factor of each layer comprising the subsurface models. For hard rock outcrops (model A4), the amplification factor within a layer has been determined by the following formula (Midorikawa et al., 1992):

$\log F_{\mathrm{amp}}=1.11-0.42 \log V_{S}$,

where $F_{\text {amp }}$ is the amplification factor, and $V_{S}\left(\mathrm{~km} \mathrm{~s}^{-1}\right)$ is the layer-average shear velocity calculated from the measured $P$-wave velocity using the formula: $V_{S}=V_{P} /(4.34-$ $\left.0.49 V_{P}\right)$. Figure 2 presents the computed accelerograms for three typical subsurface models, and Table 3 presents the measured and calculated seismic wave velocities, density, and calculated amplification factor for the principal subsurface units used in the modelling.

The predicted surface peak ground acceleration for four earthquake scenarios are plotted in Fig. 4 (see Table S1 in the Supplement for the predicted surface PGA). The models demonstrate the level of seismic hazard and ground shaking over the study area and identify regularities in the attenuation of intensities, describing the likelihood of damaging earthquakes affecting the city area. High PGA is predicted in the southern coastal and northeastern parts of the city and in some parts of the downtown. The PGA attains its maximum values for the local and extreme earthquake scenarios.

\section{Vulnerability and exposure}

The urbanization, intensive civil and industrial building, raise of underground water level, and an instability of the Caspian Sea floor have recently resulted in an increase of vulnerability of infrastructure, important communication systems, and critical facilities of the Baku city. In this section we consider a set of conditions resulting from economical, social, and environmental factors, which increase the susceptibility of a community living in Baku to the impact of regional earthquakes. We develop the cell-models describing the probabilities of moderate damage exceeding, local ground conditions (including areas affected by landslides), the density of population, and exposure. 

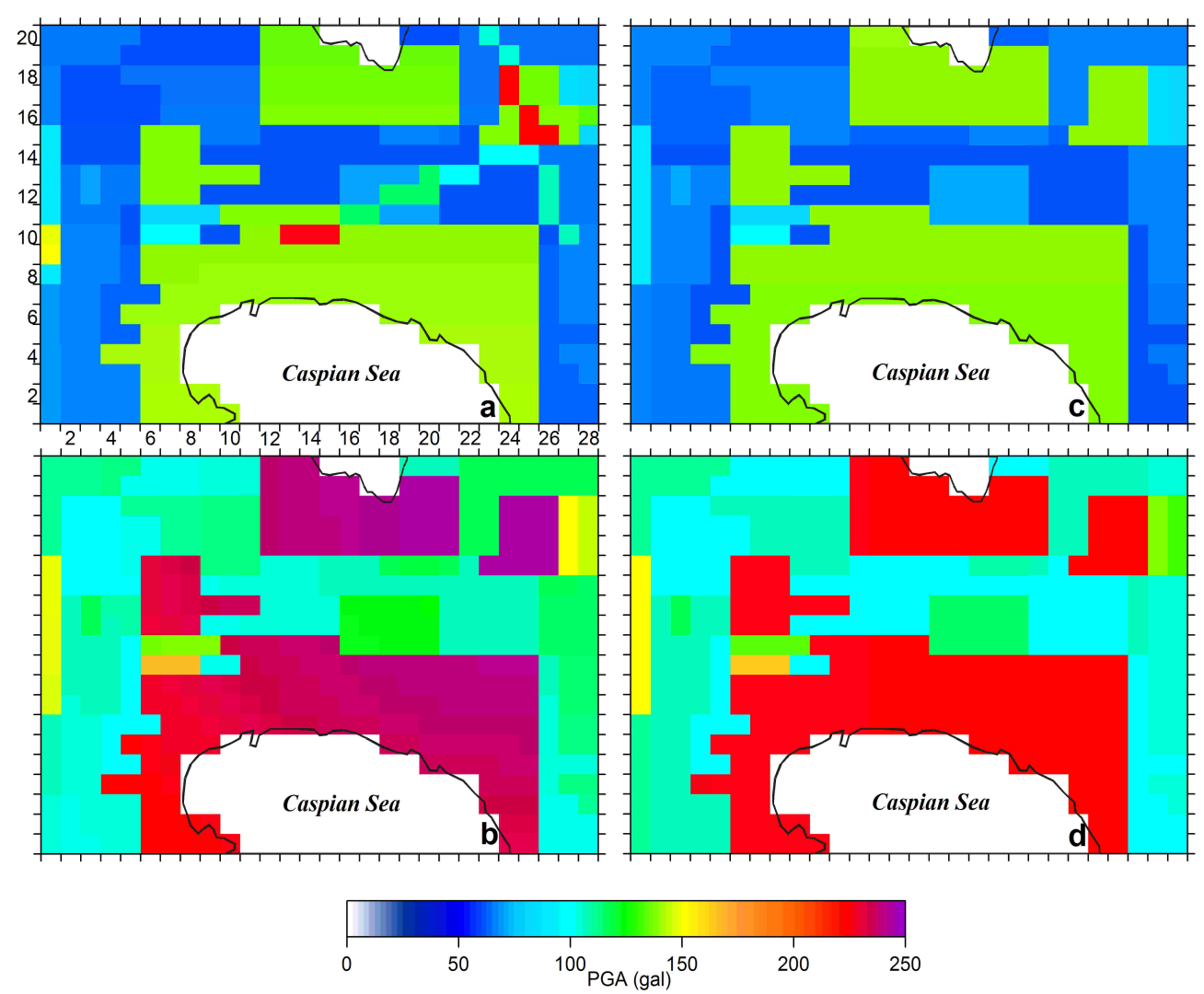

Fig. 4. Computed surface peak ground acceleration for four model scenarios: (a) near event (marked by 1 in Fig. 1); (b) local event (marked by 2); (c) far event (marked by 3), and (d) extreme event (marked by 4). Coastlines are marked by black curves here and in Figs. 5 and $7-9$.

\subsection{Probability of building damage exceeding}

The vulnerability of the buildings to an earthquake is determined on the basis of the types of building constructions (Garaveliyev, 2006). Table 4 presents the building classification based on the structure type and its specific characteristics. Brick masonry buildings, large sheet wall constructions, multi-storey apartment blocks, frame-panel buildings, and buildings constructed using non-standard code are most common building constructions in Baku. We split the building structures into four types based on the quality of constructions: high to poor quality. The type of building constructions dominating in model cells is shown in Fig. 5. The detailed distribution of building types used in this study can be found in Table S1 of the Supplement.

The buildings constructed during the late Soviet period (mainly within the period of 1950-1988) are assumed to be highly resistant to earthquakes. The assumption is based on the fact that during this period of time, buildings were erected strictly according to the existing anti-seismic building code. The degree of deterioration of the buildings constructed during the period of the XVIII to middle XX centuries is also considered. The buildings constructed after the collapse of the Soviet Union (mainly during the end of the
$\mathrm{XX}$ and beginning of XXI centuries) could be considered as the constructions with a poor seismic resistance, since the national anti-seismic building code has not been finally identified. However, there is an increasing trend amongst state authorities towards full implementation and consideration of seismic resistance regulations.

The ground shaking due to an earthquake is one of the important factors in potential damage to building structures. To determine the level of structural damage due to an earthquake, we develop the fragility functions depending on the surface peak ground acceleration $\left(A_{s}\right)$ and on building typology and seismic code design. Due to a lack of quantitative data on the building damage in Baku as a function of the level of ground shaking, we use in this study the theoretical curves of fragility, which are consistent with those used in HAZUS (2003). The fragility curves represent the probability of exceeding of moderate building damage and are modelled as cubic $\delta^{*}$-splines (Ismail-Zadeh and Tackley, 2010): for building type 1

$P=0.05 A_{s}^{3} / 0.216$,

for type 2

$P=0.26 A_{s}^{3} / 0.216$, 
Table 4. Building classification.

\begin{tabular}{|c|c|c|}
\hline Building construction type & Characteristics & $\begin{array}{l}\text { Fragility curve } \\
\text { (see Fig. 6) }\end{array}$ \\
\hline $\begin{array}{l}\text { Building constructed during } \\
\text { the period of XIX - mid XX centuries } \\
\text { Industrial buildings }\end{array}$ & $\begin{array}{l}\text { Buildings of high earthquake resistance } \\
\text { (Type 1: high quality) }\end{array}$ & 1 \\
\hline $\begin{array}{l}\text { Five-storey panel building } \\
\text { Framed, frame-panel building } \\
\text { Five-storey apartment block } \\
\text { Outhouse }\end{array}$ & $\begin{array}{l}\text { Buildings of good earthquake resistance } \\
\text { (Type 2: good quality) }\end{array}$ & 2 \\
\hline $\begin{array}{l}\text { Modern masonry construction } \\
\text { Sheet wall construction }\end{array}$ & $\begin{array}{l}\text { Buildings of moderate earthquake resistance } \\
\text { (Type 3: good to poor quality) }\end{array}$ & 3 \\
\hline $\begin{array}{l}\text { Building constructed using } \\
\text { non-standard seismic code }\end{array}$ & $\begin{array}{l}\text { Buildings of low earthquake resistance } \\
\text { (Type 4: poor quality) }\end{array}$ & 4 \\
\hline
\end{tabular}

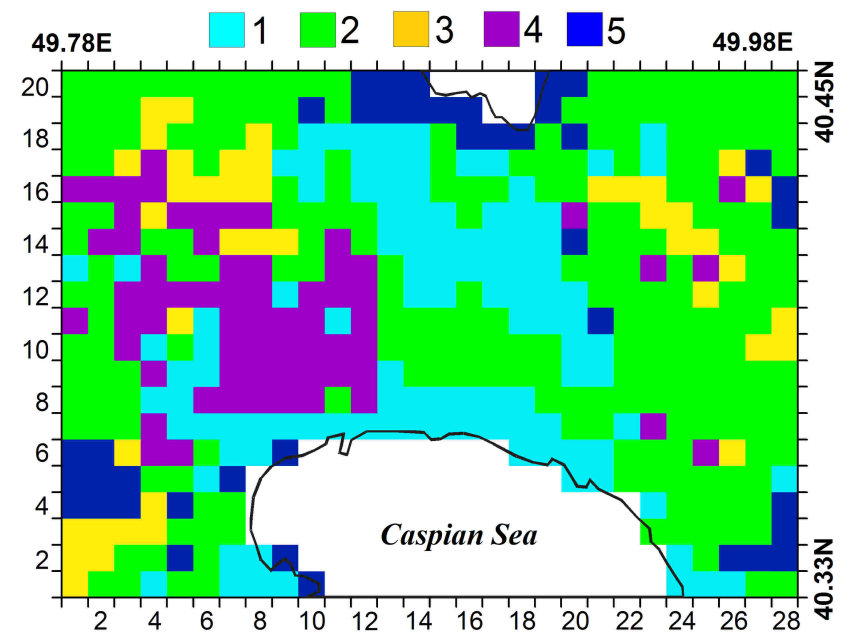

Fig. 5. Distribution of building constructions: high (type 1); good (type 2); good to poor (type 3); and poor (type 4) quality. Construction free areas are marked by 5 .

for type 3

$P=\left\{\begin{array}{c}0.2 A_{s}^{3} / 0.027, A_{s} \leq 0.3 g \\ 0.2+0.4\left(A_{s}-0.3\right) / 0.3+\left(A_{s}-0.3\right)^{2} / 0.27 \\ -\left(A_{s}-0.3\right)^{3} / 0.081, A_{s} \geq 0.3 g\end{array}\right.$

and for type 4

$P=\left\{\begin{array}{c}0.3 A_{s}^{3} / 0.027, A_{s} \leq 0.3 g \\ 0.3+\left(A_{s}-0.3\right) / 0.6+\left(A_{s}-0.3\right)^{2} / 0.27 \\ -\left(A_{s}-0.3\right)^{3} / 0.081, A_{s} \geq 0.3 g .\end{array}\right.$

where $1 g=9.8 \mathrm{~m} \mathrm{~s}^{-1}$. Figure 6 shows the fragility curves (Eqs. 5-8). For low-magnitude local event the probability of moderate damage exceeding is low compared to the highmagnitude earthquakes (near-, far- and extreme-event sce-

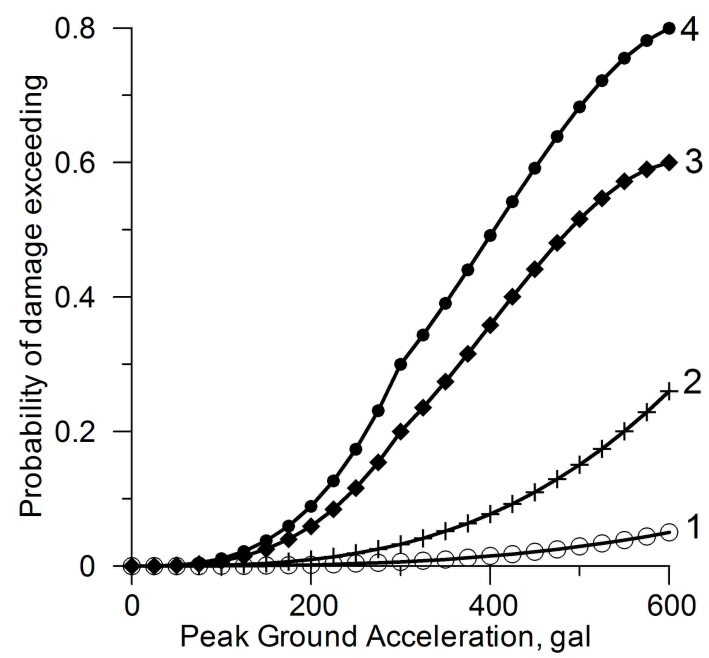

Fig. 6. Theoretical fragility curves for four types of building constructions. The curve index $i$ marks building type $i(i=1,2,3,4)$.

narios), because the shaking period is shorter, and therefore, damage is smaller for lower-magnitude earthquakes. Hence, we use fragility curve (Eq. 5) for building types 1 and 2 and curve (Eq. 6) for building types 3 and 4 in the case of the local earthquake scenario.

Using the seismic hazard models (Fig. 4), the quality of buildings (Fig. 5), and the fragility functions (Fig. 6), the probability of exceeding of moderate building damage for each cell of the modelled region is calculated (Fig. 7). The probability of the damage is determined for four earthquake scenarios (see Table S1 in the Supplement for the probability of the damage for each model cell). It is high in the westerncentral part of the town for all scenarios. The probability of moderate damage exceeding reaches its highest values for the extreme event scenario. 

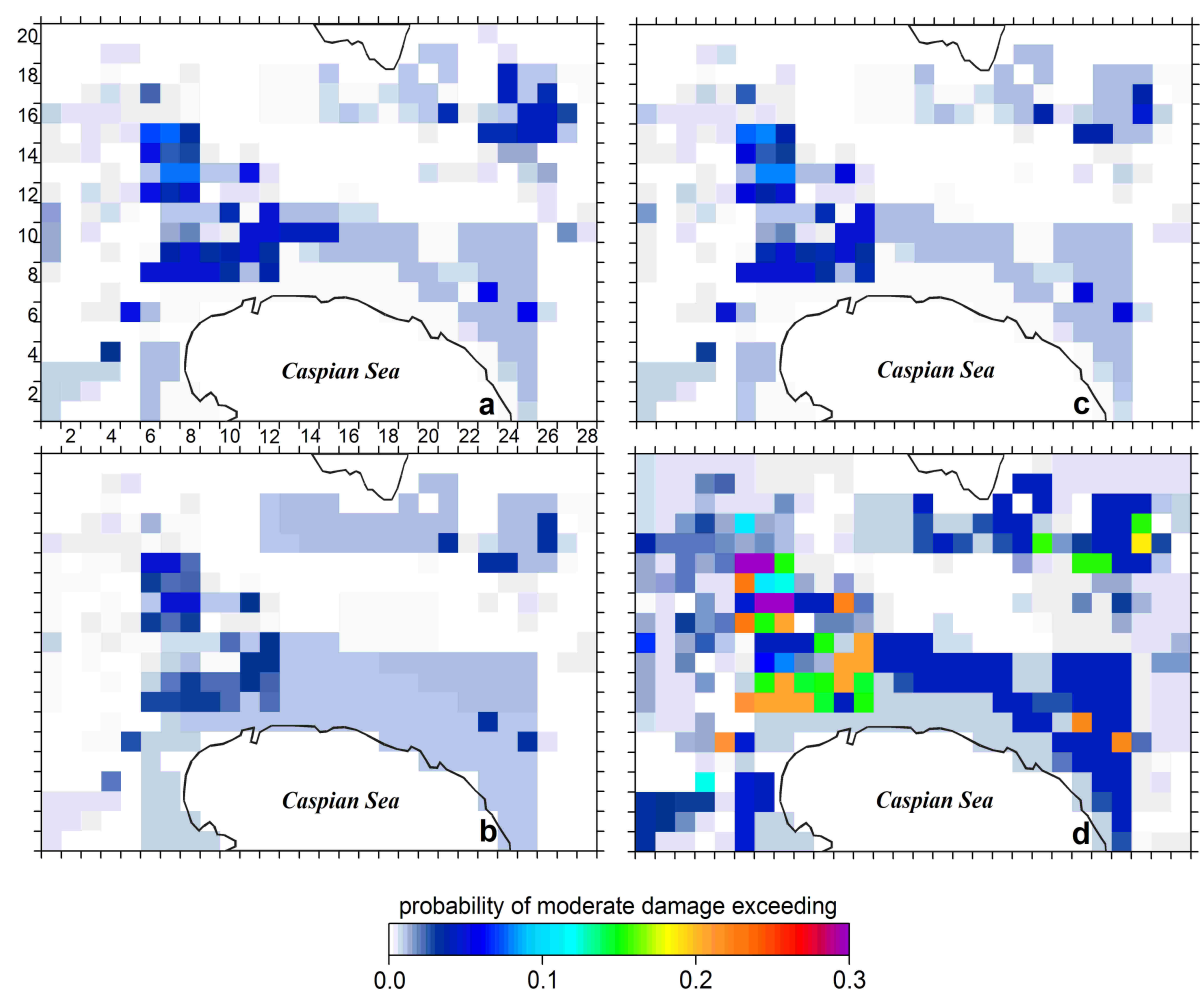

Fig. 7. Probability of exceeding moderate damage of the building structures for earthquake scenarios: (a) near event; (b) local event; (c) far event, and (d) extreme event.

Table 5. Significant landslides in the south-western part of the city and $M>4.5$ earthquakes near Baku.

\begin{tabular}{|c|c|c|}
\hline Event & Date & Description \\
\hline Landslide & 19.08.1929 & Many houses and a tram line destructed \\
\hline Earthquake & 24.12.1929 & $M 4.7,35 \mathrm{~km}$ from Baku \\
\hline Earthquake & 16.01.1951 & $M 4.9,40 \mathrm{~km}$ from Baku \\
\hline Landslide & 25.06 .1951 & Many residential and industrial houses collapsed \\
\hline Landslide & 20.11 .1990 & 28 people dead \\
\hline Earthquake & 01.06 .1992 & $\begin{array}{l}\text { M4.5 earthquake occurred in close vicinity }(1-2 \mathrm{~km}) \text { from the } \\
\text { area of landslides. No significant landslide was observed }\end{array}$ \\
\hline Landslide & 07.03 .2000 & $\begin{array}{l}23 \text { houses destructed, } 100 \text { buildings strongly damaged, } 40 \\
\text { moderately damaged, destructed gas station, shipyard, parts of } \\
\text { two principal streets. Total damage US } \$ 40 \mathrm{M}\end{array}$ \\
\hline Earthquake & 25.11 .2000 & M6.3 Caspian earthquake \\
\hline
\end{tabular}

\subsection{Local ground conditions}

Baku is located in the trough outlined by the outcrops of Quaternary limestones representing a high risk to buildings and other constructions due to soil properties. Owing to the presence of north-western dislocations from the west and east, the trough represents a fan-shaped depression (Fig. 2; Shikhalibeyli, 1996). In the studied region we identify three principal types of soil based on the standard determination of soil parameters (e.g. developed by the National Earthquake Hazards Reduction Program; http://earthquake.usgs. gov/regional/nca/soiltype/) and on the shaking amplification. Figure 8a demonstrates that the larger part of the study area is covered by stable soil types. Moderate ground conditions can be observed in the north-western and eastern parts of the city. The least stable soil types are mainly spread in the shoreline area and cross the central part of the city. 

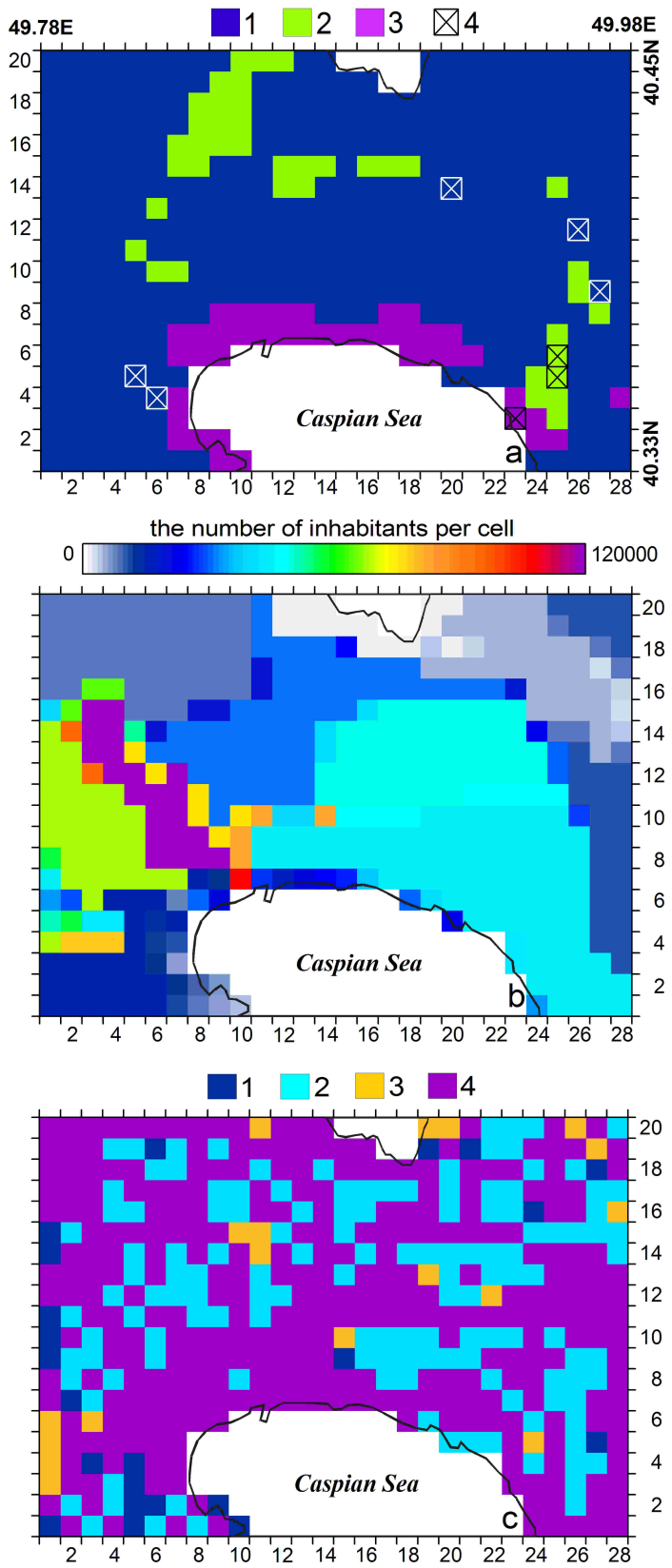

Fig. 8. Cell models of vulnerability and exposure. (a) Soil types. 1: the Quaternary sand, clay, intrusions of limestone, and sandy clay; the Upper Tertiary limestone and sandstone (minor amplification of shaking). 2: the Quaternary sand, gravel-pebble, and limestone with clay intrusions (moderate amplification of shaking). 3: watersaturated sand, clay and rubble (significant amplification of shaking). 4: landslide area. (b) Distribution of urban population. (c) Distribution of exposure. 1: low-value objects; 2: moderate-value objects; 3: high-value objects; and 4: very-high-value objects.

In the modelling we use also the information on landslides. Both types of ground failures can be observed in the Baku city: landslides with jumbled materials that start on steep slopes (as soil slides and avalanches) in the western and east- ern parts of the city; and landslides of unjumbled materials (as block slides) in the northern and eastern parts of the city. Eight of the model cells cover the known landslide areas (the cells are marked by $\mathbf{x}$ in Fig. 8a). In the past significant landslides occurred in the south-western part of the city. We do not find a strong temporal correlation between these landslides and the earthquakes occurred near Baku before or after the landslides (Table 5). Some landslides took place before significant earthquakes and other events after earthquakes. This may suggest that prior an earthquake crustal deformations and localised tectonic stresses influence a water balance in subsurface sediments and hence lead to liquefaction and to friction reduction. A landslide can then be triggered by an earthquake or can occur before the earthquake if a critical state for a slide is reached. We prescribe the value 0.9 (higher probability of a land to slide) to the cells of our model, where landslides took place in the past; whereas the cells with no landslide occurrence in the past obtain the value 0.1 . This simple discrimination of the model cells on the basis of landslide occurrence can provide information on the risk due to multi-hazard events.

\subsection{Population features}

The Baku city is fully urbanized. According to the official statistical data by January 2007 (State Statistical Committee of Azerbaijan Republic, 2008), 1893300 inhabitants lived in Baku with the population density of 889 inhabitants per $1 \mathrm{~km}^{2}$ (the area of Baku is $2192 \mathrm{~km}^{2}$ ) and with an annual population growth rate of $10.1 \%$. We consider the population density per each of nine administrative areas of Baku in this study. Figure $8 \mathrm{~b}$ illustrates the cell-model of distribution of inhabitants in Baku (see Table S1 in the Supplement for the distribution). The western and central parts of the city show densely populated lowlands.

To determine the number of injured people (including fatalities) due to full or partial collapse of the building structures, statistical data on the number of people living or working in the buildings of different types and on the number of people being indoor or outdoor at different times are required. Unfortunately, we could not collect these data for each model cell, and hence our estimations of people at earthquake risk is based on the assumption that the people stay indoors at their residential neighbourhood.

\subsection{Exposure}

Exposed value estimation provides information for disaster mitigation authorities to develop and to apply strategies and practices to minimize disaster risks throughout a society and to limit negative impact of seismic hazards. The values of exposed objects are identified through the investigation of engineering maps of Baku, which illustrate the infrastructure and critical facilities of the city. 
In this study we assume that residential and state buildings, hospitals, schools, important communication systems are much more valuable (the weighted coefficient of exposed value is prescribed to be 0.9 ) and hence more representative in terms of exposure assessment compared to parks, lakes or other natural objects (the coefficient of exposed value is prescribed to be 0.1 ). In the modelling we introduce four weighted coefficients of exposed values, based on their functioning, strategic applicability, and assignment to the national cultural heritage (see Table 6; also Table S1 of the Supplement for the weighted coefficients of exposure for each cell). The cell-model for exposed value for the Baku region is presented in Fig. 8c.

\section{Earthquake risk estimation}

\subsection{Method}

The general methodology of earthquake risk estimation is based on the convolution of all three main components: seismic hazard, vulnerability and exposure. Vulnerability convolves, in its turn, several components, such as ground conditions, quality of structures, and population. Moreover, the risk value is assumed to be proportional to the regional Gross Domestic Product (GDP) per capita (Papadopoulus and Arvanitides, 1996; Dunbar et al., 2003). The GDP of an individual cell is determined using the following relation:

GDP per cell $=$ regional GDP $\times \frac{\text { population in cell }}{\text { regional population }}$

Table S1 of the Supplement presents the GDP values for each model cell.

To evaluate earthquake risk for the Baku city for four earthquake scenarios (far, near, local and extreme events), we convolve six discrete functions determined at each cell of the model $S(28 \times 20$ cells $)$ : the seismic hazard function $f_{1}$, which represents a surface PGA normalized with the same normalization factor for all earthquake scenarios; landslides occurrence (function $f_{2}$ ); vulnerability in terms of the building structures damage (function $f_{3}$ ), and the normalized population features (function $f_{4}$ ); exposed value (function $f_{5}$ ); and normalized GDP per capita (function $f_{6}$ ). The values of the functions (dimensional values in the case of functions $f_{1}$, $f_{4}$, and $f_{6}$ ) over each model cell are presented in Table S1 of the Supplement.

In the model domain $S$ we compute the discrete convolution as:

$$
\begin{aligned}
& g_{p+1}\left(i^{*}, j^{*}\right)=\sum_{j=1}^{n_{y}} \sum_{i=1}^{n_{x}} \alpha_{p}^{-1}\left(i-i^{*}, j-j^{*}\right) f_{p+1}(i, j) \\
& g_{p}\left(i^{*}, j^{*}\right) ; p=1, \ldots, 5 ; g_{1}=f_{1}
\end{aligned}
$$

where $\left(i^{*}, j^{*}\right)$ is the mid-point of a model cell, $n_{x}=28$, and $n_{y}=20$. The resultant discrete function $g_{6}(i, j)$ represents the normalized earthquake risk. To normalize the function $f_{k}(x, y)(k=4,6)$, its values are divided by its maximum value $\max _{x, y} f_{k}(x, y)$. The functions $\alpha_{p}$ are represented in the following form:

$\alpha_{p}\left(i-i^{*}, j-j^{*}\right)=1+\beta_{p}\left[\frac{\left(i^{*}-i\right)^{2}}{n_{x}^{2}}+\frac{\left(j^{*}-j\right)^{2}}{n_{y}^{2}}\right]$,

where $\beta_{p}>0$ is the weighted coefficients. The effect of convolution of the functions is more pronounced with decrease of $\beta_{p}$. At large $\beta_{p}$ values, the only term to dominate in the sum Eq. (10) is the term $f_{p+1}\left(i^{*}, j^{*}\right) g_{p}\left(i^{*}, j^{*}\right)$ at $(i, j)=$ $\left(i^{*}, j^{*}\right)$, and the resultant $g_{6}(i, j)$ will be close to the product of the six functions at each cell.

\subsection{Results}

The convolution of the considered functions for the earthquake risk estimation is summarised in Fig. 9 for two values of parameter $\beta=\beta_{p}(p=1,2,3,4$, and 5). The dependence of earthquake risk function on the weighted parameter $\beta$ is illustrated in Figs. S1-S4 of the Supplement. The results show clearly that the earthquake risk does not change significantly with various earthquake scenarios. Risk for all earthquake scenarios depends essentially on the quality of buildings (Fig. 5) and the probability of their damage (Fig. 7) and on the distribution of urban population (Fig. 8b) and exposure (Fig. 8c), and to a lesser extent on the pattern of peak ground acceleration (Fig. 4).

The western-central part of Baku is exposed to the highest risk independent on the distance of the earthquakes from the city and/or the magnitude of modelled events. This result is not far from being realistic. For example, the central part of Baku was mostly affected by the $1963(M=6.5)$ and the $2000(M=6.3)$ Caspian earthquakes resulting in the indirect social and economic problems in these areas. The high risk predicted for the central part of the city is associated with the highest density of population ranging between 106 190-118 100 inhabitants (see also Fig. 8b). The parameter GDP for the cells of this area varies in the range of AZM $262844-465210$ (AZM=Azeri Manat) on average. Along with the existence of buildings of high and good quality in this part of the city, there are constructions erected by using a non-standard building code. The exposure of the infrastructure and critical facilities in the central part of the city (e.g. residential buildings, hospitals, schools, commercial buildings, governmental and state buildings, nation-valued objects, important communication systems) contributes to the high earthquake risk values. The pattern of earthquake risk follows the pattern of seismic hazard, but does not mimic it because of other factors contributing to risk. For example, the area in the western part of the city, where seismic hazard is predicted to be moderate, falls into the area of high risk because its high vulnerability and high values of exposure. Ground condition does not influence much the 
Table 6. Infrastructure exposure classification.

\begin{tabular}{llc}
\hline Name of the objects & Characteristics & $\begin{array}{c}\text { Weighted coefficient } \\
\text { of exposed value }\end{array}$ \\
\hline Park, lake, and other natural objects & Low-value objects & 0.1 \\
$\begin{array}{l}\text { Street, road, square, and their intersections } \\
\text { Culture-valued objects }\end{array}$ & Moderate-value objects & 0.3 \\
$\begin{array}{l}\text { Residential objects, hospital, school, commercial, } \\
\text { governmental and state buildings, nation-valued } \\
\text { object, important communication system }\end{array}$ & Very-high-value objects & 0.6 \\
\hline
\end{tabular}

overall results, since Quaternary terrigenous sediments are capable to absorb significantly the amplification of shaking. At the same time, Quaternary carbonate sediments and water-saturated terrigenous sediments generate the significant amplification of shaking resulting to higher vulnerability and contributing to higher earthquake risk.

The sensitivity analysis performed for several parameters (e.g. quality of structures, exposed values, population features) show that changes in values of these parameters influence insignificantly the resulting earthquake risk values. The compiled databases need to be refined, especially for the central part of Baku. Meanwhile the databases of several important parameters for earthquake risk estimation developed in this study could simplify the procedure for re-evaluation of earthquake risk, which strongly depends on time. The Baku city undergoes further development of infrastructure, critical facilities, growth of population and building construction, which will change the value of risk due to earthquakes. Nevertheless, the results obtained in this study can allow elaborating strategic long-term plans for the earthquake risk mitigation in the Baku city.

\section{Discussion and conclusion}

In this paper we have developed earthquake risk models for the Baku city based on the deterministic (scenario-based) seismic hazard models, building stock, distribution of population, ground conditions and landslide occurrence, exposure of the infrastructure, and gross domestic product per capita. The results of the study can assist in the assessment of the effectiveness of mitigation measures in reducing seismic risk. The developed models of earthquake risks in Baku show that preventive measures are still required to mitigate aftermaths of potential extreme seismic events (regional earthquakes with magnitude 7 and larger). These measures should include (i) an urgent adoption of a decision on the national building code; (ii) construction of earthquake resistant building before the decision is taken, especially in the city center; (iii) increasing level of preparedness for disaster events; (iv) raising awareness of population about possible large earthquakes in the region; and some other preventive measures (see Ismail-Zadeh and Takeuchi, 2007). The 2000 $M=6.3$ Caspian earthquake near Baku demonstrated that even a slight initial damage can lead to significant damage and fatalities later (e.g. a partial damage of the wall due to the earthquake in one of the buildings in the Baku centre resulted in the building's collapse and the human death in a few weeks after the earthquake).

The method of DSHA used in this study does not take into account the occurrence frequency of the ground motion, meanwhile the temporal characteristics of ground motion are an integral part of seismic hazard and must be considered in engineering design, particularly for seismic risk analysis. Recently Nunziara et al. (2010) argued that the use of the one-dimensional SHAKE method could result in underestimation of the ground shaking due to lateral variations in the subsurface sediments; namely, the SHAKE's results show the reduction in amplitudes of acceleration and the shift of resonance frequencies towards lower frequencies compared to the two-dimensional model for dynamic ground response.

Effective seismic risk mitigation requires more comprehensive methodologies to overcome limitations of probabilistic and deterministic seismic hazard assessment. A realistic estimate of the expected ground motion can be obtained using vast seismological, geophysical, and geodetic data and statistical techniques to analyse the data as well as physical models of earthquake preparation and rupture processes (e.g., Klügel et al., 2006; Panza et al., 2010).

The site effects are usually associated with local subsurface conditions, which change the level of ground shaking in comparison with standard attenuation relations. Meanwhile Molchan et al. (2010) showed that a local fault geometry (rather than sub-surface geology) significantly influence ground shaking. Incorporation of the knowledge on the geometry of regional fault systems into the analysis of seismic hazard can allow improving the results of hazard assessment. The methodology presented here can be improved also by incorporating the probability distribution of the aggregated risk due to a strong earthquake (Kontorovich et al., 1973). A probabilistic assessment of risk can include the uncertainties of an earthquake epicentre occurring anywhere within the study region, different magnitude levels, ground motion 

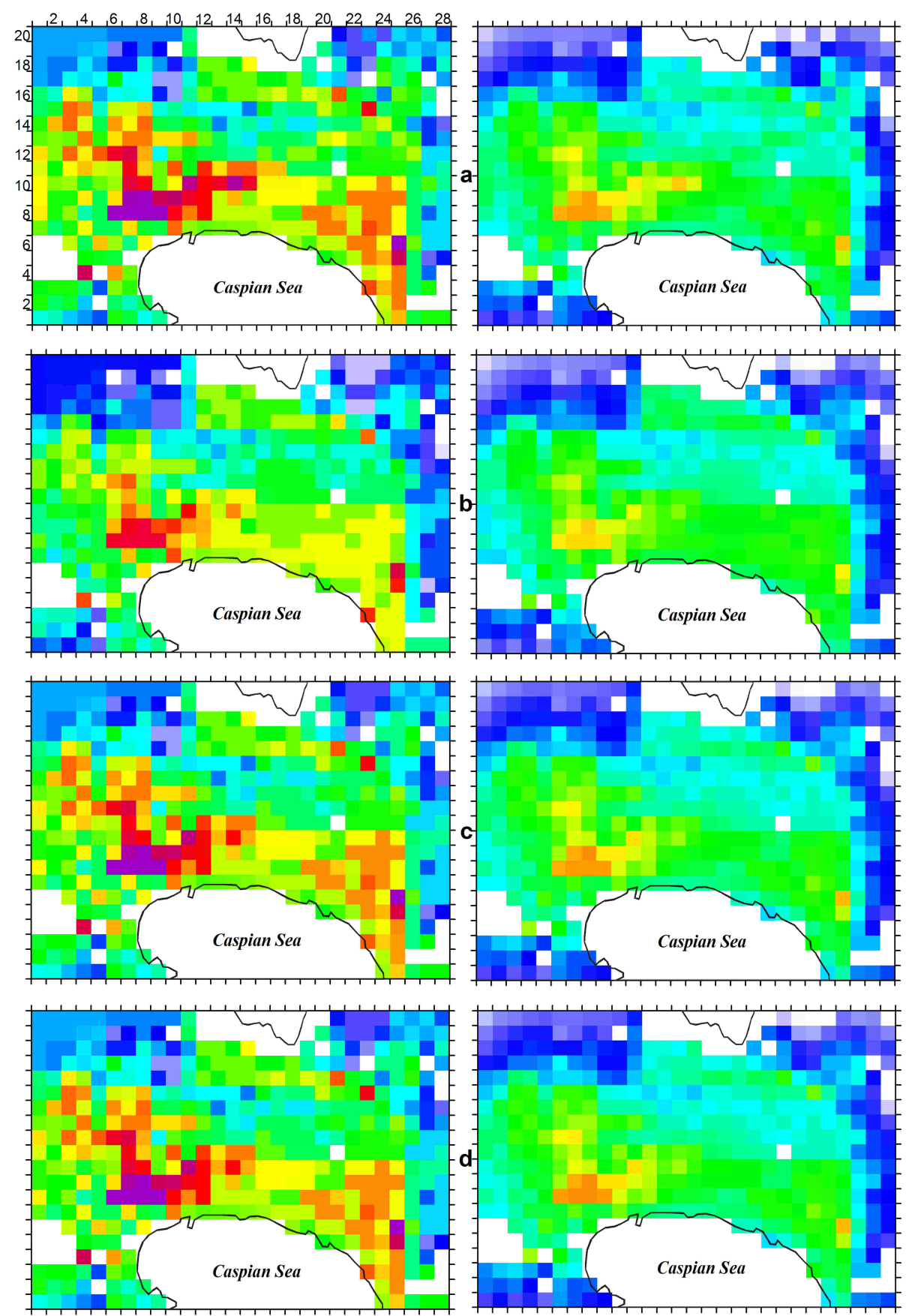

no risk

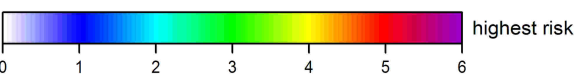

Fig. 9. Earthquake risk models for four earthquake scenarios: (a) near event; (b) local event; (c) far event, and (d) extreme event. The left and right panels present the model results for the weighted parameter $\beta=10^{10}$ and $\beta=10^{3}$, respectively.

amplitudes at different sites, presence of different earthquake related hazards (in addition to landslides considered in this work, liquefaction and fault rupture can be incorporated in the model) and their magnitude, and variability of exposure.

Despite the developed models do not take into account some details related to seismic hazard assessment, vulner- ability and exposed values in the region, the model estimations could provide enough information for decision makers. The results might represent an interest for land-use planning within an intensive infrastructure development of the Baku city and for the insurance companies operating in the region. 


\section{Supplementary material related to this article is available online at: http://www.nat-hazards-earth-syst-sci.net/10/2697/2010/ nhess-10-2697-2010-supplement.pdf.}

Acknowledgements. We thank John Anderson, Fahraddin Kadyrov, Birgit Müller, and Behrouz Panahi for discussion on regional geodynamics and seismicity, tectonic stress, and seismic hazards. We are very grateful to Giuliano Panza, Vladimir Sokolov, Zhongliang $\mathrm{Wu}$, and an anonymous reviewer for their review of the manuscript and constructive comments. GB was supported by the German Academic Exchange Service (DAAD) during his visit to the Karlsruhe Institute of Technology. A support by the German Research Foundation (DFG IS 203/1-1) and the French Ministry of Research is also acknowledged. Figure 1 is prepared using the Seismic-Eruption visualization software. Figure 2 uses two base maps obtained from 2009 Google-Map data \& 2009 Europa Technologies and from 2009 Google-Imaginary \& 2009 DigitalGlobe, GeoEye, Map data \& Europa Technologies.

Author contribution. The authors are listed in the alphabetic order. AIZ outlined the research, formulated the problem, designed numerical algorithms for risk assessment, and performed risk analysis. GB collected the data for this study and performed the seismic hazard analysis. JLM took part in analysis of earthquake risk and discussions of the results. All authors contributed to writing the paper.

Edited by: M. E. Contadakis

Reviewed by: Z. Wu and G. F. Panza

\section{References}

Agamirzoyev, R.: Seismotectonics of the Azerbaijan part of the Greater Caucasus, Elm, Baku, 124 pp., 1987 (in Russian).

Allen, M., Jones, S., Ismail-Zadeh, A., Simmons, M., and Anderson, L.: Onset of subduction as the cause of rapid PlioceneQuaternary subsidence in the South Caspian basin, Geology, 30(9), 775-778, 2002.

Aptikayev, F. and Kopnichev, Y.: Considering focal earthquake mechanism at the prediction of strong motion parameters, Doklady/Transactions of the U.S.S.R. Academy of Sciences, 247(4), 822-825, 1979 (in Russian).

Babayev, G.: Seismic hazard assessment for Baku city and Absheron peninsula, Azerbaijan, in: Recent Geodynamics, Georisk and Sustainable Development in the Black Sea to Caspian Sea Region, edited by: Ismail-Zadeh, A., Conference Proceedings of American Institute of Physics, Melville, New York, 825, 113119, 2006.

Beer, T. and Ismail-Zadeh, A. (Eds.): Risk Science and Sustainability, Kluwer Academic Publishers, Dordrecht, 256 pp., 2003.

Boghdanovitch, G.: Remarques sur ke tremblement de terre a chemakha le 31 janvier 1902, in: Comptes Rendue des Seances, Tome I, Academie Imperiale des Sciences, St.-Petersbourg, 282291, 1904

Charbe, M. S.: Organisation des stations sismiques a Bakou et a Krasnovodsk, in: Comptes Rendus des Seances de la Commis- sion Sismique Permanente. Academie Imperiale des Sciences, St. Petersbourg, 364-366, 1904.

Cornell, C. A.: Engineering seismic risk analysis, B. Seismol. Soc. Am., 58, 1583-1606, 1968.

Dunbar, P. K., Bilham, R. G., and Laituri, M. J.: Earthquake loss estimation for India based on macroeconomic indicators, in: Risk Science and Sustainability, edited by: Beer, T. and Ismail-Zadeh, A., Kluwer Academic Publishers, Dordrecht, 163-180, 2003.

Garaveliyev, E.: Earthquake hazards and estimations of probable damages of industrial and civil buildings in Baku city, $\mathrm{PhD}$ thesis, Geological Institute, Azerbaijan National Academy of Sciences, Baku, 147 pp., 2006 (in Azeri).

Gasanov, A.: Earthquakes of Azerbaijan for 1983-2002, Elm, Baku, 118 pp., 2003 (in Russian).

HAZUS: Multi-hazard loss estimation methodology (HAZUSMH-MR4), Technical manual, Federal Emergency Management Agency (FEMA), Washington, D.C., http://www.fema.gov/ library/viewRecord.do?id=3731 (accessed 31.05.2010), 2003.

Idriss, I. M. and Seed, H. B.: Seismic response of horizontal soil layer, Journal of the Soil Mechanics and Foundations Division ASCE, 94, 1003-1031, 1968.

Ismail-Zadeh, A.: Migration of seismic activity in the Caspian Sea, in: Computational Seismology and Geodynamics, 3, edited by: Chowdhury, D. K., American Geophysical Union, Washington, D.C., 125-129, 1996.

Ismail-Zadeh, A. and Tackley, P.: Computational Methods for Geodynamics, Cambridge University Press, Cambridge, 332 pp., 2010.

Ismail-Zadeh, A. and Takeuchi, K.: Preventive disaster management of extreme natural events, Natural Hazards, 42, 459-467, 2007.

Ismail-Zadeh, A., Sokolov, V., and Bonier, K.: Geodynamics, seismicity and seismic hazard of the south-eastern Carpathians, Natural Hazards, 42, 493-514, 2007.

Jackson, J., Priestley, K., Allen, M., and Berberian, M.: Active tectonics of the South Caspian Basin, Geophys. J. Int., 148, 214 245, 2002.

Kadirov, A., Mammadov, S., Reilinger, R., and McClusky, S.: Global positioning system measurements of tectonic deformation in Azerbaijan: New constraints on active faulting and earthquake hazards, Proceedings of the Azerbaijan National Academy of Sciences, Earth Sciences, 1, 82-88, 2008.

Kantorovich, L., Keilis-Borok, V. I., and Molchan, G.: Seismic risk and principles of seismic zoning, in: Computational and Statistical Methods for Interpretation of Seismic Data, edited by: KeilisBorok, V. I., Nauka, Moscow, 3-20, 1973 (in Russian).

Klügel, J. U., Mualchin, L., and Panza, G. F.: A scenario-based procedure for seismic risk analysis, Eng. Geol., 88, 1-22, 2006.

Kondorskaya, N. V. and Shebalin, N. V. (Eds.): New Catalog of Strong Earthquakes in the USSR From Ancient Times Through 1977, World Data Center for Solid Earth Geophysics, Report SE31, Boulder, Colorado, 608 pp., 1982.

Levitski, G.: Bulletin de la Commission Centrale Sismique Permanente (Annee 1902. Janvier-juin), Academie Imperiale des Sciences, St.-Petersbourg, 62 pp., 1902.

Midorikawa, S., Matsuoka, M., and Sakugawa, K.: Evaluation of site effects on peak ground acceleration and velocity observed during the 1987 Chiba-ken-toho-oki earthquake, J. Struct. Constr. Eng., Architectural Institute of Japan, 442, 71-78, 1992 (in 
Japanese with English abstract).

Mir-Babaev, M. Y.: Azerbaijan's oil history, Azerbaijan International, 10, 34-40, 2002.

Molchan, G., Kronrod, T., and Panza, G. F.: Hot/cold spots in Italian macroseismic data, Pure Appl. Geophys., doi:10.1007/s00024-010-0111-3, 2010.

National Earthquake Information Center: United States Geological Survey, Golden, Colorado, World Earthquake Data Centre, Electronic catalog, (http://earthquake.usgs.gov/earthquakes/ eqarchives/epic/; accessed on 1 June 2010), 1977-2001.

Nunziata, C., Vaccari, F., and Panza, G. F.: The Mw 6.3, 2009 LAquila earthquake: Linear and nonlinear site effects, in: Urban Habitat Constructions Under Catastrophic Events: Proceedings of the Cost C26 Action Final Conference, edited by: Mazzolani, F. M., Taylor \& Francis Group, London, 99-104, 2010.

Panahi, B.: Estimation of geological hazards and risks in Azerbaijan, in: Shamakha Earthquake 1902, edited by: Kheyrullaoglu, G., Nafta-Press, Baku, 37-63, 2003 (in Russian).

Panahi, B.: Seismicity in Azerbaijan and adjacent Caspian Sea, in: Recent Geodynamics, Georisk and Sustainable Development in the Black Sea to Caspian Sea Region, edited by: Ismail-Zadeh, A., Conference Proceedings of American Institute of Physics, Melville, New-York, 825, 3-10, 2006.

Panza, G. F., Irikura, K., Kouteva, M., Peresan, A., Wang, Z., and Saragoni, R.: Advanced seismic hazard assessment, Pure Appl. Geophys., doi:10.1007/s00024-010-0179-9, 2010.

Papadopoulos, G. and Arvanitides, A.: Earthquake risk assessment in Greece, in: Earthquake Hazard and Risk, edited by: Schenk, V., Kluwer Academic Publishers, Netherlands, 221-229, 1996.

Reilinger, R. E., McClusky, S. C., Souter, B. J., Hamburger, M. W., Prilepin, M. T., Mishin, A., Guseva, T., and Balassanian, S.: Preliminary estimates of plate convergence in the Caucasus Collision Zone from global positioning system measurements, Geophys. Res. Lett., 24, 1815-1818, 1997.
Reilinger, R., McClusky, S., Vernant, P., Lawrence, S., Ergintav, S., Cakmak, R., Ozener, H., Kadirov, F., Guliev, I., Stepanyan, R., Nadariya, M., Hahubia, G., Mahmoud, S., Sakr, K., ArRajehi, A., Paradissis, D., Al-Aydrus, A., Prilepin, M., Guseva, T., Evren, E., Dmitrotsa, A., Filikov, S. V., Gomez, F., Al-Ghazzi, R., and Karam, G.: GPS constraints on continental deformation in the Africa-Arabia-Eurasia continental collision zone and implications for the dynamics of plate interactions, J. Geophys. Res., 111, B05411, doi:10.1029/2005JB004051, 2006.

Schnabel, P. B., Lysmer, J., and Seed, H. B.: SHAKE, A computer program for earthquake response analysis of horizontally layered sites. Tech Report No EERC 72-12, Earthquake Engineering Research Centre, College of Engineering, University of California, Berkley, 102 pp., 1972.

Shikhalibeyli, E.: Some Aspects of Geological Structures and Tectonics of Azerbaijan, Elm, Baku, 82 pp., 1996 (in Russian).

State Statistical Committee of Azerbaijan Republic: Statistical Yearbook of Azerbaijan, Seda, Baku, (http://www.azstat.org/ publications/yearbook/SYA2008/en/index.shtml; accessed on 1 June 2010), 2008.

Sultanova, Z.: Earthquakes of Azerbaijan for the Period of 19661982 Years, Elm, Baku, 96 pp., 1986 (in Russian).

Tonouchi, K. and Kaneko, F.: Methods of evaluating seismic motion at base layer. OYO Technical Report No. 6, Japan, 12-14, 1984 (in Japanese).

USGS: U.S. Geological Survey Earthquake Hazards Program: Seismic Hazard Map for Haiti Region, http://neic.usgs.gov/neis/ eq_depot/2010/eq_100112_rja6/neic_rja6_w.html (accessed on 1 June 2010), 2010.

Veber, M. V.: Recherches preliminaries sur le tremblement de terre a Chamakha, Comptes Rendue des Seances, Tome I, Academie Imperiale des Sciences, St.-Petersbourg, 238-241, 1904. 